\title{
Campuses as Faux Nations
}

\section{George R. La Noue}

The problem is not the affectation adopted by many campuses labeling their sports fan base as "nations," with their own websites and Facebook pages. To be a citizen of those "nations," it helps if you are consumed with the coming and going of millionaire coaches and the minutiae of recruiting. Thus, the University of Michigan has its Wolverine Nation and, not to be outdone, the University of Texas has two such groups, the Longhorn Nation and Burnt Orange Nation. My campus uses the term \#RetrieverNation, though actual measures of attendance would make retriever village more accurate, but that appellation lacks a bit of swagger.

Instead, the problem is the widespread practice by many campuses in defining community membership in ways that deny their students the civil liberties and civil rights all other Americans are guaranteed. Thus, when forty-year old veterans enroll for even one part-time course, they may find that First and Fourteenth Amendment rights existing off campus no longer apply to them as students. They may seem to have joined a different nation with various sets of ambiguous rules. Some campuses place those sanctions not only on campus-based actions, but on social media comments made in the distant past as well.

In reality, public campuses are bound by constitutional provisions, and most "private" institutions are covered as well by federal statutes and regulations if they accept public funding. ${ }^{1}$ Furthermore, they usually have stated commitments about academic freedom and non-discrimination, even if their actual practices do not align. ${ }^{2}$ But those legal protections are not what is encountered

1 George La Noue, "Title IX for Men," Law and Liberty, February 23, 2021.

2 Colleen Flaherty, "Divided Wisconsin Supreme Court Backs Marquette Faculty Blogger," Inside Higher Ed, July 9, 2018.

George R. La Noue is Emeritus Professor of Public Policy and Political Science at the University of Maryland Baltimore County and author of the book Silenced Stages: The Loss of Academic Freedom and Campus Policy Debates (2019); glanoue@umbc.edu. La Noue last appeared in AQ with "Seeking Diversity, Selecting Discrimination" in the fall of 2020. 
in many student handbooks and in other rules set and enforced by university bureaucrats.

After successfully suing the University of Michigan, the University of Texas, the University of Illinois at Urbana-Champaign, and Iowa State University, Speech First has just sued Virginia Tech for violating its students' speech rights. ${ }^{3}$ Virginia Tech, aka "Hokie Nation," is a public land grant campus founded in 1872, now enrolling about 34,000 students. The litigation lists twenty individual administrators and board members as defendants. That campus has made potentially punishable student speech involving "telling unwelcome jokes about someone's identity," “urging religious beliefs on someone who finds it unwelcome," using the university's computer networks for "partisan political purposes" or "unwarranted annoyance," or being present when someone makes an inappropriate comment and not reporting it. Bias related incidents regarding twelve different group identities can be referred for formal disciplinary proceedings, if they occur on or off campus or on social media. Students are also forbidden from distributing literature or petitioning for signatures "without prior written authorization from the University.”

So how did American higher education arrive at so many censorious rights-negating policies and what can be done about them? The origins of the campus as a community uber alles has many contributors. Campuses now often regard students fundamentally as customers who must be kept emotionally safe and whose group identities must never be offended. Campus presidents have begun to sound like department store owners who like Target managers must seek to avoid offense to groups strong enough to protest. ${ }^{4}$

After Carol Swain, a tenured Vanderbilt Professor of Political Science and Law, wrote an op-ed criticizing Islam in Nashville's major newspaper, 1,500 students and alumni signed a petition demanding her suspension and requiring additional diversity training. ${ }^{5}$ Chancellor Nicholas S. Zeppos responded by disavowing her views and, "Ensuring that our campus is a safe, welcoming place and supportive environment for every member of the Vanderbilt community has been and always will be our top priority."

3 Speech First v. Timothy Sands, President, complaint filed April 8, 2021.

4 Madeline Osburn, "Target Swiftly Bans Book On Behalf Of Anonymous Twitter User Crying 'Transphobia,"' The Federalist, November 13, 2020.

5 "Professor Carol Swain to Leave Her Faculty Post at Vanderbilt University," Journal of Blacks in Higher Education, January 30, 2017. 
From the customer-first top priority, safe spaces, speech codes, and bias response teams began to develop. Campuses passively accepted speaker disinvitations and disruptions, if student activists protested that events even where attendance was completely voluntary made them feel uncomfortable. Recent surveys by Gallup, Heterodox Academy, Brookings, and CATO show that students have become afraid to voice their opinions, while some of their peers were willing to shut down events where the opinions voiced were different from theirs.

These restrictions on free speech, association rights, and even religious liberty were often designed by a new force on campus - the diversity, equity, inclusion, and social justice bureaucrats. Their numbers have grown enormously in recent years, ${ }^{6}$ and they often see their role as developing and protecting groups whose ideology are consistent with their own. ${ }^{7}$ Thus, an easy interaction was developed between censorious identity politics on and off campus, where some groups are nurtured and others ignored or discouraged.

Why weren't faculty able to resist the bureaucratic impulses to restrict speech? It should have been obvious that, if administrations were able to dictate the boundaries of campus discourse for students, it would lead to students demanding limits to professorial speech, even in classroom dialogues or commentary on controversial matters. In 2020-2021, the Foundation for Individual Rights in Education (FIRE) received 449 complaints from faculty about abridgment of their free speech and due process protections. ${ }^{8}$

There are three reasons for the general faculty acquiescence to speech controls. First, tenured faculty who have had speech protections are now only a fraction of campus instructors, with the American Association of University Professors reporting only 27 percent of all faculty on the tenure track. ${ }^{9}$ Second, even tenured faculty have begun to lose power in campus governance and to retreat from that responsibility. ${ }^{10}$ Third, tenured faculty have increasingly adopted ideological and pedagogical positions consistent with administrative censors. ${ }^{11}$

6 David Randall, "Social Justice Education in America," National Association of Scholars, November 29, 2019.

7 Steven Kolowich, "When Does a Student-Affairs Official Cross the Line?" The Chronicle of Higher Education, August 5, 2016, A26.

$8 \quad$ FIRE, "Intellectual Freedom dies when questions are punished," March 1, 2021.

9 Colleen Flaherty, "A Non-Tenure-Track Profession?," Inside Higher Ed, October 12, 2018.

10 Benjamin Ginsberg, The Fall of the Faculty: The Rise of the All-Administrative University and Why it Matters, (New York: Oxford University Press, 2011).

11 Samuel J. Abrams, "Think Professors are Liberal? Try School Administrators," The New York Times, October 16, 2018, https://www.nytimes.com/2018/10/16/opinion 
Consequently, it has become the judiciary's role to protect campus speech from the functionaries who would undermine it. The premise for these rulings in academic disputes was stated clearly by the Supreme Court in 1972 and it runs directly contrary to the view that campuses are separate nations that may restrict speech for their own purposes. At Central Connecticut State University, undergraduates wanted to start a local chapter of the national organization Students for a Democratic Society (SDS). The campus president denied recognition of the chapter which would have granted the chapter access to campus facilities for meetings, the use of the campus bulletin board and notices in the campus newspaper which other groups enjoyed, on the grounds that the national SDS organization had a philosophy of disruption and violence. The District and Circuit Court of Appeals agreed with him, but a unanimous Supreme Court overturned and declared:

Yet the precedents of this Court leave no room for the view that, because of the acknowledged need for order, First Amendment protections should apply with less force on college campuses than in the community at large. Quite the contrary. The college classroom, with its surrounding environs, is peculiarly the "marketplace of ideas," and we break no new constitutional ground in affirming the Nation's dedication to safeguarding academic freedom. (Emphasis in the original). ${ }^{12}$

Litigation can be arduous and expensive, however. Although the University of Washington recently had to pay $\$ 122,000$ in legal fees to settle a free speech infringement after a federal judge issued a temporary restraining order, ${ }^{13}$ most challenged campuses just drop the offending policies without further cost to them. This option tempts campus lawyers to advise waiting until the litigation battle has begun and then make necessary changes to moot the case creating a loss of standing. But circuit courts examining speech codes and bias response teams have disagreed because these devices "act[ed] by way of the implicit threat of punishment and intimidation to quell speech" and "represent[ed] the clenched fist in the velvet glove of student speech regulation." ${ }^{14}$ Still, the

12 Healy v. James (408 U.S.169, 180, 1972).

13 Katherine Long, "UW to pay $\$ 122,000$ in legal fees in a settlement with College Republicans," The Seattle Times, June 18, 2020.

14 Speech First, Inc. v. Schlissel, 936 F.3d 756, 765 (6 $6^{\text {th }}$ Cir.2019); Speech First v. Fenves, 979 F.3d 319, $338\left(5^{\text {th }}\right.$ Cir.2020). 
universities walked away from these losses with no other injury, except their taxpayer funded legal expenses.

Recently, however, courts have begun to signal there might be consequences in the form of damages for those who are responsible for obviously unconstitutional policies. In March 2021, the Supreme Court decided Uzuegbunam v Preczewski, with Chief Justice Roberts the lone dissenter. Georgia Gwinnett College had a speech zone policy which forced students who wished make a public speech to block a time to use in a tiny space. Uzuegbunam, a Christian convert, registered to make a proselytizing speech, but due to a student complaint the College determined that his speech "disturbs the peace and/or comfort” of students or faculty. Shortly after the Alliance Defending Freedom (ADF) sued, the College changed its policy and Uzuegbunam had graduated, thus possibly mooting the case. ADF argued, however, that the plaintiff was entitled to nominal damages, but the Eleventh Circuit disagreed, creating a split in the circuits which enabled the Supreme Court decision. Justice Thomas writing for the Court declared, "Because every violation [of a right] imports damage, nominal damages can redress Uzuegbunam's injury even if he cannot or chooses not to quantify that harm in economic terms." ${ }^{15}$

A few weeks later, a circuit court weighed in on the question of damages when students rights are abridged. In 2018, the University of Iowa deregistered a small campus group called Business Leaders in Christ (BLinC) which intends "to create a community of followers of Christ ... to share wisdom on how to practice business that is both Biblical and founded on God's truth.” Deregistration meant that BLinC could not participate in on-campus recruitment fairs, access university facilities or receive funding and benefits available to other student groups. The conflict occurred when a gay student sought a leadership position in the group, but was rejected because he stated that he opposed BLinC's religious beliefs and stated he would not follow them. In the District Court's decision, Judge Stephanie Rose found that the university had not followed its human rights policy consistently and permitted other groups to limit membership, but she ruled that university officials had qualified immunity and could not be forced to pay damages. The Eighth Circuit disagreed with that part of her decision and sent the case back for a determination of damages. ${ }^{16}$

$15 \quad 502$ U.S....2021.

16 Ryan J, Foley, "Court: U of lowa officials can be held liable for targeting Business Leaders in Christ." Des Moines Register, March 21, 2021. 
On July 16,2021, a unanimous Eighth Circuit panel returned to the damages question in Intervarsity Christian Fellowship (ICF) v. University of Iowa. The court ruled that campus administrators engaged in viewpoint discrimination by deregistering ICF after losing the BLinC decision. Moreover, the administrators had no qualified immunity and were liable for damages because the law was now clear. The panel also quoted Justice Thomas, who recently said "why should university officers, who have time to make calculated choices about enacting or enforcing unconstitutional policies, receive the same protections as a police officer who makes a split-second decision to use force in a dangerous setting?" (Hoggard v. Rhodes, 2021). The University has decided not to appeal the panel decision.

The reality is that there are more than 3,000 campuses in the United States. The efforts by ADF, FIRE, Speech First, and other organizations have been essential in establishing legal precedents and at least providing temporary relief to victims of speech suppression on various campuses. But the new judicial openness to holding campus authorities accountable through the imposition of personal damages offers an alternative to the "whack a mole" approach now used. To create damage precedents, litigation will have to be more time consuming and expensive requiring attorney fees to be sought when cases are won. Extensive discovery and depositions with the creators of speech suppression policies will be necessary. Who drafted the policy and which administrators and board members reviewed it? What role did campus activists or outside groups play in policy design? Was legal counsel involved and what was their advice? Given that sort of record, a court can determine whether damages should be assessed, how much they should be, and who should pay them? When those sorts of precedents are established, we will begin to see more responsible speech policies consistent with constitutional rights in higher education nationwide. 